\title{
Competitive exclusion and habitat segregation in seasonal macroinvertebrate assemblages in temporary ponds
}

\author{
Margarita Florencio ${ }^{1,4}$, Carola Gómez-Rodríguez ${ }^{2,5}$, Laura Serrano ${ }^{3,6}$, AND \\ Carmen Díaz-Paniagua ${ }^{1,7}$ \\ ${ }^{1}$ Doñana Biological Station-CSIC, Américo Vespucio s/n, 41092, Seville, Spain \\ ${ }^{2}$ Facultad de Biología, Universidad de Santiago de Compostela, Rúa Lope Gómez de Marzoa s/n, \\ 15782 Santiago de Compostela, Spain \\ ${ }^{3}$ Department of Plant Biology and Ecology, University of Seville, P.O. Box 1095, 41080, Seville, Spain
}

\begin{abstract}
Seasonal variation in macroinvertebrate assemblages usually is attributed to environmental variability, but this relationship is unclear in temporary ponds because they are highly dynamic across time. We assessed the influence of environmental variables and biotic interactions on macroinvertebrate community structure in 22 temporary ponds sampled monthly over 2 successive years that differed in rainfall. We hypothesized that abiotic and biotic variables would have different influences on macroinvertebrates having different dispersal abilities (capable of dispersal or not) and dietary modes (predaceous or not). Constrained Analysis of Principal Coordinates showed mainly seasonal influences on community assembly. During the filling phase, water-column total $\mathrm{P}(\mathrm{TP})$ and $\mathrm{pH}$ were important, whereas maximum depth, $\mathrm{pH}$, electrical conductivity, and dissolved $\mathrm{O}_{2}$ were important during the aquatic phase. When ponds were close to desiccation, water-column electrical conductivity and TP and sediment organic matter were most influential. Predation by urodele adults occurred early in the inundation cycle and by urodele larvae when the ponds were close to desiccation. Negative species checkerboards (patterns of species noncoexistence) revealed that primarily competitive exclusion was in operation immediately after pond inundation, whereas competitive exclusion and habitat segregation were operating in tandem during the subsequent months. During the drying phase, general deterioration of environmental conditions and high pressure exerted by biotic interactions may trigger macroinvertebrate strategies to survive desiccation. Variability in pond characteristics allows macroinvertebrate species to assemble and disassemble in response to pond inundation-desiccation cycles and, thus, supports high biodiversity in the area.
\end{abstract}

Key words: habitat checkerboard, competitive checkerboard, urodeles, predation, invertebrate composition, community structure, Mediterranean ponds, hydroperiod, pond filling, pond desiccation.

Temporary ponds are fluctuating aquatic systems characterized by recurrent desiccation phases. In many of these ponds, inundation usually starts at the onset of the rainy season, whereas the duration of the recurrent dry phase is less predictable (Williams 1997). Thus, temporary ponds are ideal systems in which to study the assembly and disassembly of

\footnotetext{
${ }^{4}$ Present address: Azorean Biodiversity Group (CITA-A) and Platform for Enhancing Ecological Research and Sustainability (PEERS), Departamento de Ciências Agrárias, Universidade dos Açores, 9700-042 Angra do Heroísmo, Terceira, Azores, Portugal. E-mail: margarita@ebd.csic.es

${ }^{5}$ E-mail addresses: carola@ebd.csic.es

6 serrano@us.es

7 poli@ebd.csic.es
}

communities over the short periods of time that correspond with inundation-desiccation cycles. Moreover, temporary ponds may harbor real metacommunities (a set of local communities linked by the dispersal of multiple, potentially interacting species; Leibold et al. 2004). In particular, macroinvertebrate species can form perfect metacommunities that contain both active and passive dispersers, whose establishment depends on abiotic conditions and biotic interactions (Patrick and Swan 2011). However, this phenomenon is difficult to study because environmental characteristics in temporary ponds show dramatic seasonality (Serrano and Toja 1995, Bazzanti et al. 1996, Gómez-Rodríguez et al. 2009), as do invertebrate assemblages (Jeffries 1994, Serrano and Toja 1998, Florencio et al. 2009b). 
During the annual period of pond inundation, seasonal wet phases have been described in temporary ponds that correspond with seasonal variation in macroinvertebrate assemblages (Bazzanti et al. 1996, Boix et al. 2004, Culioli et al. 2006, Florencio et al. 2009b): 1) the filling phase is a short period that takes place just after ponds form in the pond network at the beginning of the rainy season, 2) the intermediate or aquatic phase is a long period during which macroinvertebrate assemblages become well established and species run through their life cycles, and 3) the drying phase starts with the desiccation of the first ponds in the area, forcing macroinvertebrate species to use strategies, such as active dispersal and the development of drought-resistant stages, to survive the dry period (Bilton et al. 2001b, Williams 2006).

Community assembly implies that compositional changes take place through a combination of species colonization and extinction events in a newly formed or disturbed ecological habitat. In general, both habitat segregation (i.e., species have different niche constraints) and species competition (i.e., biotic interactions drive competitive exclusion) can cause species exclusion, leading to these compositional changes (Diamond 1975). In temporary-pond networks, aquatic communities assemble and disassemble most years in synchrony with the seasonal wet phases described above. Therefore, changes in species composition follow temporal changes that can be better understood through a hierarchical filtering model of community assembly (see Poff 1997). First, organisms must successfully colonize the pond after its initial inundation (i.e., dispersal filter). Second, assemblages become established in the pond network as species experience habitat segregation as a result of environmental filtering (e.g., quality of the aquatic environment and physical-habitat filters). Last, pond assemblages are composed of some remaining, coexisting species, whereas others have been excluded as a result of competition (i.e., interspecific interaction filters). When noncoexistence of species occurs more frequently than expected by chance (i.e., negative species checkerboards), environmental variables and biotic interactions are assumed to operate together to determine assemblage composition. Such patterns of noncoexistence may be attributed to competitive exclusion (Stone and Roberts 1992), which may be based in competition for limited resources and modified by predation effects (Englund et al. 2009), but other possible underlying causes include species segregation into nonoverlapping niches (i.e., habitat segregation) and allopatric speciation in a biogeographic and evolutionary historical context (Gotelli and McCabe 2002).
An ideal model temporary-pond network with which to evaluate the dynamic biotic and abiotic seasonality of macroinvertebrate assemblages exists in Doñana National Park (southwestern Spain). In years of heavy rainfall, $>3000$ water bodies that vary greatly in hydroperiod (i.e., water permanence) can form in the Doñana landscape (Gómez-Rodríguez et al. 2011). This natural pond network has a high conservation status and has been included in the RAMSAR convention since 1982. It was designated a World Heritage Site in 1995 by the United Nations Educational, Scientific, and Cultural Organization (UNESCO).

We evaluated the role of seasonal biotic interactions and environmental characteristics in structuring entire macroinvertebrate assemblages. We also separately examined their effects on the following groups of macroinvertebrates: dispersers, nondispersers, predators, and nonpredators. Predators may control wetland community structure (Wellborn et al. 1996) and urodeles commonly occur in Doñana temporary ponds (DíazPaniagua et al. 2005), so we also assessed the role of urodeles in determining macroinvertebrate assemblage composition. The selected ponds represented the wide range of hydroperiods found in the network and were studied across 2 years that differed in rainfall. We proposed 4 hypotheses: 1) environmental variability should play an important role in structuring assemblages during the filling phase of the inundation cycle, when a high number of species hatch from resistant forms found in the sediment and macroinvertebrate dispersers colonize the filling ponds, 2) habitat segregation should be more important in assemblages of nondispersing macroinvertebrates because of their inability to escape unfavorable conditions, 3) urodele and macroinvertebrate predation should play an important role in determining seasonal macroinvertebrate assemblage structure, and 4) the relative importance of competitive exclusion and habitat segregation in structuring macroinvertebrate assemblages should increase across the inundation-desiccation cycles. The underlying rationale is 2-fold. First, the number of species colonizing the pond after inundation can increase over time, and thus, the number of possible biotic interactions should increase as well. Second, changes in environmental variables during the drying phase can trigger development of macroinvertebrate strategies to survive desiccation.

\section{Methods}

\section{Study area}

We analyzed the environmental characteristics of 22 temporary ponds in the Doñana Biological Reserve. This area is between the Atlantic coast and the mouth 
of the Guadalquivir River. The climate is Mediterranean subhumid, with mild winters and hot, dry summers. Rainfall is very variable, but heavy floods tend to occur in the autumn and winter (see Siljeström et al. 1994, García-Novo and Marín Cabrera 2006 for a detailed description of the area). Most ponds in Doñana are fed by rainfall and a shallow water table that rises above the surface after heavy rainfall. Most ponds also are temporary and usually fill during the autumn or winter, whereas desiccation occurs in the late spring or summer (Díaz-Paniagua et al. 2010). A detailed description of the physicochemical characteristics of Doñana temporary ponds, including most of our study ponds, was given by Gómez-Rodríguez et al. (2009) and Florencio et al. (2009b). Vegetation in the ponds was mainly composed of meadow plants, such as Mentha pulegium L., Illecebrum verticillatum L., or Hypericum elodes L., in the littoral zone, whereas aquatic macrophytes, such as Juncus heterophyllus Dufour, Myriophyllum alterniflorum DC. in Lam \& DC., Callitriche obtusangula Le Gall, and Ranunculus peltatus Schrank, were common in deeper waters (Díaz-Paniagua et al. 2010).

Our study lasted from October 2005 to August 2007. A given year's annual rainfall was taken to be the precipitation falling from $1^{\text {st }}$ September to $31^{\text {st }}$ August in the following year. This amounted to $468.3 \mathrm{~mm}$ the $1^{\text {st }}$ year (hereafter referred to as the dry year) and $716.9 \mathrm{~mm}$ the $2^{\text {nd }}$ year (hereafter referred to as the wet year). Each year, we selected our study ponds so as to include the widest range of hydroperiods possible, and thus, pond heterogeneity in the study area was well represented. In the dry year, we sampled 19 temporary ponds. We excluded one of these ponds from the analyses because it held water for $<1$ mo. In the wet year, more ponds representing a wider hydroperiod range were formed than during the dry year. To assess the widest possible hydroperiod range during the wet year, we included 3 of these new ponds in the data set. However, the total number of sampled ponds was 19, i.e., the same number as the year before. Most temporary ponds were inundated from February to June in the dry year and from October to July in the wet year, although the pond with the longest hydroperiod held water even during August in both years. Most ponds filled at approximately the same time, after the first heavy rainfall each year, but the number of ponds that held water decreased successively starting in March in the dry year and in April in the wet year. We defined hydroperiod as the number of months in which ponds were flooded in a given year and categorized the ponds in relation to each year's longest recorded hydroperiod. In our analyses, hydroperiod categories for the dry year were: short $(<2.5 \mathrm{mo}, n=4$ ponds), intermediate (2.5-3.5 mo, $n=9$ ponds), and long ( $>3.5 \mathrm{mo}, n=5$ ponds). The 3 new ponds added to the data set in the wet year were the first to desiccate and were placed in an additional category: ephemeral ponds. These ephemeral ponds had the shortest hydroperiod that year ( $<6.4 \mathrm{mo}, n=4$ ponds) compared to short (6.4-7 mo, $n=4$ ponds), intermediate ( $7-7.5 \mathrm{mo}, n=7$ ponds), and long $(>7.5 \mathrm{mo}, n=4$ ponds) hydroperiod ponds (for further details on pond hydroperiods, see Florencio et al. 2009b). Hydroperiod classification of Doñana temporary ponds usually is consistent across years with different inundation patterns (Gómez-Rodríguez et al. 2009), as is the case in our study.

\section{Sampling of macroinvertebrate assemblages}

We used a dip-net (1-mm mesh size) to sample the presence and abundance of macroinvertebrates in the ponds on a monthly basis. We swept a stretch of water $\sim 1.5 \mathrm{~m}$ long in each sampling unit. In each pond, we sampled at points separated by a minimum distance of $5 \mathrm{~m}$ along 1 or 2 transects from the littoral to the open water. The number of sampling points was proportional to pond size. We also took additional samples in microhabitats that were not represented in these transects. The maximum number of samples per pond ranged from 6 to 13 in the month of maximum inundation. As pond size decreased during the season, the number of samples taken was reduced accordingly. The appropriateness of this sampling procedure was demonstrated through sample-based rarefaction by Florencio et al. (2011). We identified, counted in situ, and released most captured macroinvertebrates. We preserved individuals of unidentified species in $70 \%$ ethanol for identification in the laboratory. We identified adults and larvae separately (hereafter referred to as taxa for simplicity). In general, taxa were identified to the species (most adults) or genus (most larvae) level, although most members of the orders Basommatophora, Diptera, Haplotaxida, and Lumbricula and saldid Hemiptera were identified only to the family level. In the course of our sampling, we noted the presence of the 3 species of urodele larvae that occur in Doñana ponds: Triturus pygmaeus (Wolterstorff, 1905), Lissotriton boscai (Lataste, 1879), and Pleurodeles waltl Michahelles, 1830. All 3 species are predators of aquatic macroinvertebrates (Díaz-Paniagua et al. 2005).

\section{Pond characteristics}

In each pond and sampling month, we measured maximum depth (with a graduated pole at the deepest point of the pond), electrical conductivity at 
$20^{\circ} \mathrm{C}$ (on the bed using a Multi-range Conductivity Meter HI 9033; HANNA Instruments, Cluj-Napoca, Romania), $\mathrm{pH}$ (on the bed using a $\mathrm{pH}$ meter $\mathrm{HI}$ 991000, HANNA Instruments, Amorim, Portugal), dissolved $\mathrm{O}_{2}$ concentration, and temperature $\left({ }^{\circ} \mathrm{C}\right)$ in situ (both of the latter on the bed using a YSI 550A; Yellow Springs Instruments, Yellow Springs, Ohio). We collected $500 \mathrm{~mL}$ of surface water to measure, following acid digestion in the laboratory (Golterman 2004), the concentration of total P (TP) in the water. We collected surface-sediment samples ( $5 \mathrm{~cm}$ in depth) and measured sediment organic matter (SOM; 3 replicates; loss on ignition, $450^{\circ} \mathrm{C}, 5 \mathrm{~h}$ ) and sediment total P (STP: 2 replicates) in the laboratory. We estimated STP from dissolved inorganic $\mathrm{PO}_{4}{ }^{3-}$ obtained following the method of Murphy and Riley (1962), in which the ignited sediment is acid-digested with $0.5 \mathrm{M} \mathrm{H}_{2} \mathrm{SO}_{4}$ and $\mathrm{K}_{2} \mathrm{~S}_{2} \mathrm{O}_{8}(0.5-1 \mathrm{~g})$ at $120^{\circ} \mathrm{C}$ for $4 \mathrm{~h}$ (Golterman 2004). We measured sediment total $\mathrm{Fe}$ (STFe) concentration in the sediment colorimetrically after sample digestion (2 replicates) by means of o-phenanthroline with ascorbic acid as the reducing agent (Golterman 2004). We did not consider water temperature in our statistical analyses because of its dependence on seasonal climatic variation. We replaced missing values for environmental variables with the mean of that variable for the month (Leps and Ŝmilauer 2003).

\section{Macroinvertebrate, urodele, and environmental data}

We constructed a macroinvertebrate matrix, an environmental matrix, and a urodele matrix with the data obtained per pond and month for the 2 study years. These matrices were based on the presence/ absence of macroinvertebrate taxa, values of the environmental variables, and presence/absence of urodele larvae, respectively. We divided the macroinvertebrate matrix into 4 additional matrices: 1) the disperser matrix contained adult taxa of macroinvertebrates capable of flight; 2) the nondisperser matrix contained larvae and adult taxa of macroinvertebrates incapable of flight; 3) the predator matrix contained predaceous macroinvertebrate larval and adult taxa; and 4) the nonpredator matrix contained nonpredaceous macroinvertebrate larval and adult taxa. In the environmental matrix, except for STFe and SOM, we $\log _{e}(x+1)$-transformed all values to achieve approximate normality. We applied the Sørensen index to construct a macroinvertebrate dissimilarity matrix for our analyses. We generated separate monthly matrices from the large matrices that included data per pond and month (i.e., from the overall macroinvertebrate, disperser, nondisperser, predator, nonpredator, environmental, and the urodele matrices).

\section{Data analyses}

We ran 2 Constrained Analyses of Principal Coordinates (CAP) to detect the monthly relationship between macroinvertebrate assemblage composition and environmental variables and urodele occurrence. We evaluated the explanatory capacity of the environmental matrices and the urodele matrices to predict the macroinvertebrate assemblage matrices with R software (version 2.11.1; R Development Core Team, Vienna, Austria) (vegan package; Oksanen et al. 2010). We also ran separate monthly CAP analyses to examine how well the environmental matrices predicted the values of disperser, nondisperser, predator, and nonpredator matrices. We used a forward stepwise procedure (described by Blanchet et al. 2008) to retain environmental variables. The $p$-value of the marginal effect of the variable had to be $<0.1$ in a model that included all other variables. We used Monte Carlo tests to assess significance (999 permutations). In all these analyses, we excluded significantly correlated environmental covariables $\left(r_{\mathrm{S}}>0.6\right)$.

To identify the months in which biotic interactions significantly affected macroinvertebrate assemblage structure, we calculated the checkerboard score (C scores; Stone and Roberts 1990) using each monthly macroinvertebrate matrix. The $C$ score quantifies the number of pairs of species that do not coexist in a given area (Stone and Roberts 1990). Noncoexistence can result from competitive exclusion (Stone and Roberts 1990, 1992), concurrent interspecific competition and predation (Englund et al. 2009), or habitat segregation (Gotelli and McCabe 2002, Heino 2009). We used a modified $C$ score index that was normalized by the number of species $m$ and sites $n$ (Ulrich and Gotelli 2012b):

$$
N C \text { score }=4 \sum_{i j}\left(N_{i}-N_{i j}\right)\left(N_{j}-N_{i j}\right) / m n(m-1)(n-1)
$$

where $N_{i}$ and $N_{j}$ are the row totals (number of occurrences) for species $i$ and $j$ and $N_{i j}$ is the number of co-occurrences of both species. We calculated NC scores using the program Turnover (version 1.1; Ulrich 2012). This program partitioned the NC score into 3 components: $N C$ score $=C_{\text {Turn }}+C_{\text {Segr }}+C_{\text {Mixed }}$, where $C_{\text {Turn }}$ corresponds to the checkerboard pairs that stem from species turnover, $C_{\text {Segr }}$ to those that do not stem from species turnover, and $C_{\text {Mixed }}$ estimates the segregation attributable to both $C_{\text {Turn }}$ and $C_{\text {Segr }}$ (Ulrich and Gotelli 2012b). Partitioning the NC score into these 3 components helps disentangle the respective roles that competitive exclusion (i.e., effects of species competition and predation) and habitat segregation play in structuring the macroinvertebrate 

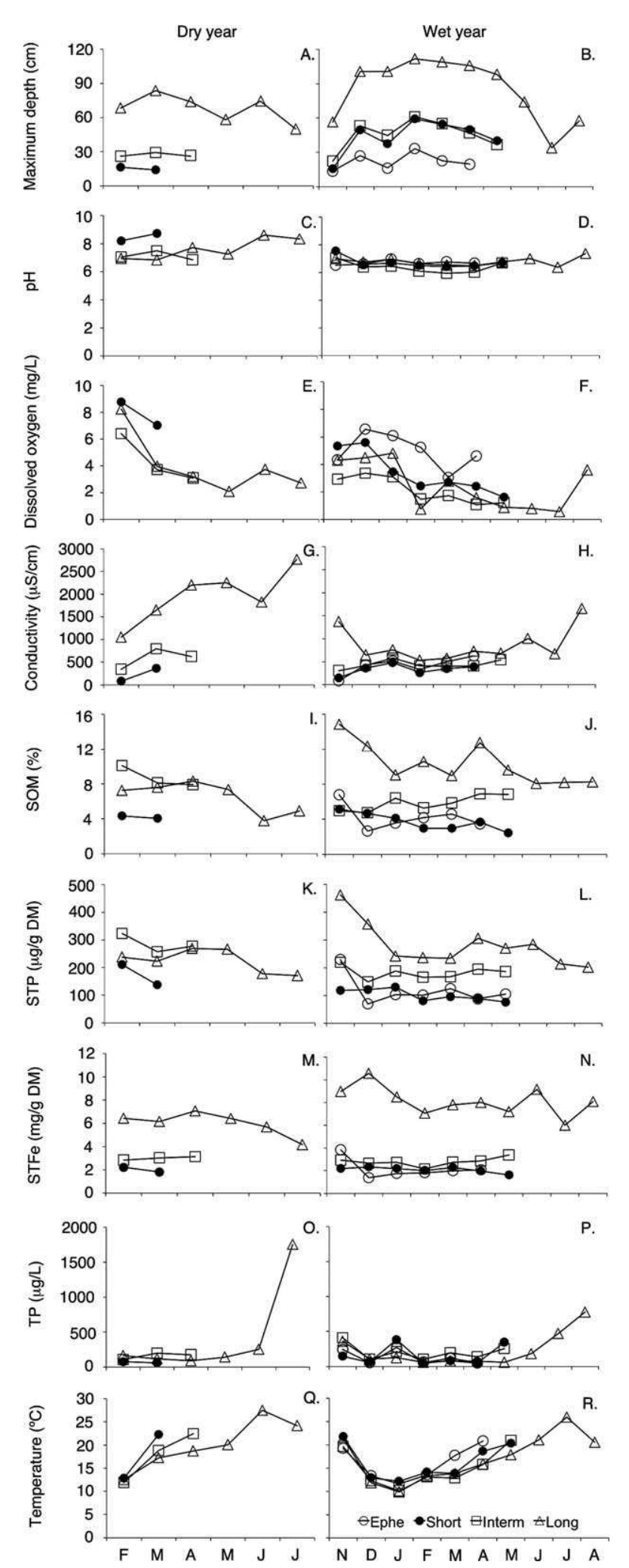

FIG. 1. Monthly variation in maximum depth (A, B), pH $(C, D)$, dissolved $\mathrm{O}_{2}(\mathrm{E}, \mathrm{F})$, conductivity $(\mathrm{G}, \mathrm{H})$, organic matter $(\mathrm{SOM})(\mathrm{I}, \mathrm{J})$, sediment total $\mathrm{P}(\mathrm{STP})(\mathrm{K}, \mathrm{L})$, sediment total Fe (STFe) $(\mathrm{M}, \mathrm{N})$, water-column total P (TP) $(\mathrm{O}, \mathrm{P})$, and assemblages. Significance was assessed using a matrix sorted according to reciprocal averaging after 1000 randomizations using the proportional-proportional (PP) null model (Ulrich and Gotelli 2012a). In the PP null model, the presence of rows and columns varies randomly, but the total row and column averages in the set of PP matrices are unbiased and match those of the original matrix. This model seems to be more appropriate than the fixed-fixed (FF) null model when evaluating the significance of NC score partitioning. The latter model fixes the number of occurrences within rows and columns (Ulrich et al. 2009). The PP null model is more restrictive and better represents ecological community assemblages than the FF null model (Ulrich and Gotelli 2012a).

\section{Results}

Monthly environmental variation in relation to pond hydroperiod

Doñana temporary pond waters generally had highly variable environmental characteristics spanning a wide hydroperiod range, from ponds with ephemeral hydroperiods exhibiting shallow waters, to ponds holding deeper waters for longer periods of time (Fig. 1A, B). For instance, $\mathrm{pH}$ ranged from 4.5 to 9.5, although $\mathrm{pH}$ was typically circumneutral (Fig. 1C, D). As ponds filled, waters were generally well oxygenated (Fig. 1E, F) and had low values of electrical conductivity $(<200 \mu \mathrm{S} / \mathrm{cm}$ for most ponds; Fig. 1G, H). However, ponds with long hydroperiods had high electrical conductivity values. After the filling stage, the concentration of dissolved $\mathrm{O}_{2}$ was drastically reduced, whereas electrical conductivity values gradually increased until complete desiccation. SOM (Fig. 1I, J), STP (Fig. 1K, L), and STFe (Fig. 1M, $\mathrm{N})$ concentrations were moderate throughout the inundation period. TP (Fig. 1O, P), SOM, and STP and STFe concentrations were maximal in long hydroperiod ponds just before desiccation. Hence, the maximum values of TP $(1800 \mu \mathrm{g} / \mathrm{L})$, SOM $(21 \%)$, STP $(700 \mu \mathrm{g} / \mathrm{g}$ dry mass [DM]) and STFe $(20 \mathrm{mg} / \mathrm{g}$

$\leftarrow$

temperature $(\mathrm{Q}, \mathrm{R})$ averaged by pond hydroperiod category in the dry (A, C, E, G, I, K, M, O, Q) and wet (B, D, F, H, J, L, $\mathrm{N}, \mathrm{P}, \mathrm{R})$ years. In the dry year, months are indicated from February (F) to July (J), and in the wet year from November (N) to August (A). DM = dry mass. Ephe = ponds with ephemeral hydroperiod. Short $=$ ponds with short hydroperiod, Interm $=$ ponds with intermediate hydroperiod, Long $=$ ponds with long hydroperiod. 


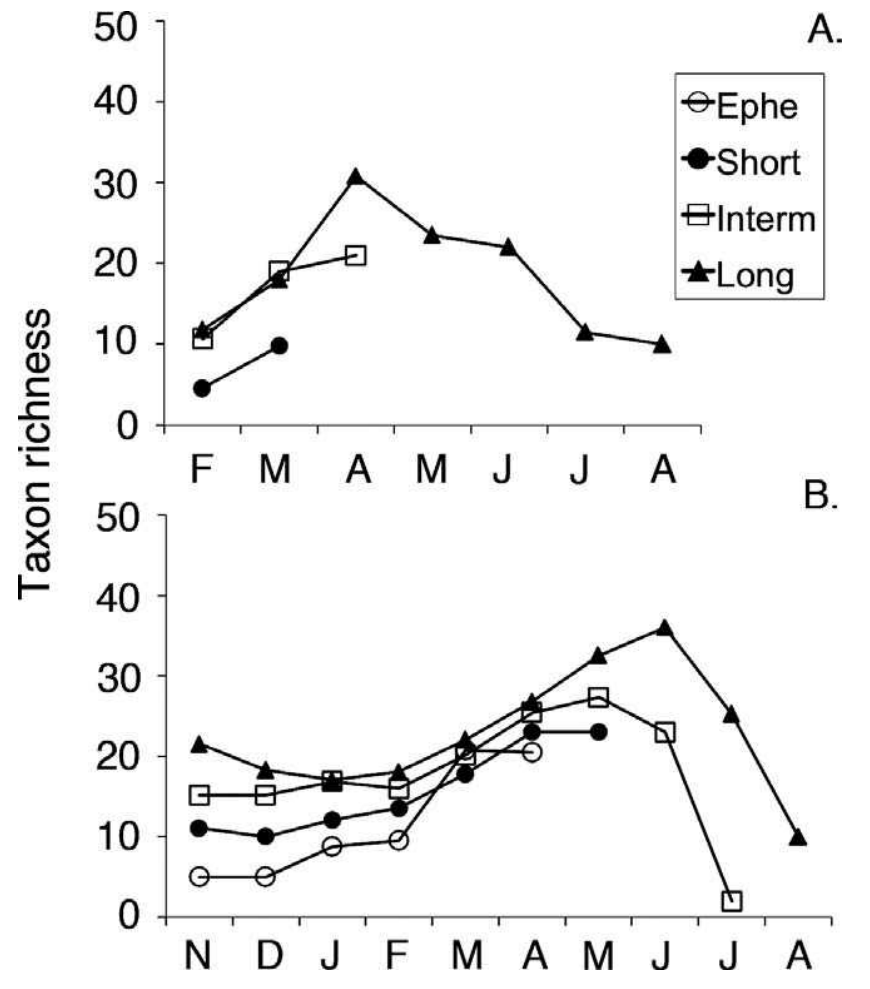

FIG. 2. Monthly variation in the number of macroinvertebrate taxa (taxon richness) averaged by pond hydroperiod category and month in the dry (A) and wet (B) years. In the dry year, months are indicated from February (F) to August (A), and in the wet year from November (N) to August (A). Ephe $=$ ponds with ephemeral hydroperiod. Short $=$ ponds with short hydroperiod, Interm = ponds with intermediate hydroperiod, Long $=$ ponds with long hydroperiod.

$\mathrm{DM}$ ) were detected in one of these ponds. Temperature reached its lowest values in winter (Fig. 1Q, R). SOM, STP and STFe concentrations were highly correlated (SOM and STP concentration, $r_{\mathrm{S}}=0.88$, $p<0.001 ; \mathrm{SOM}$ and STFe concentration, $r_{\mathrm{S}}=0.63$, $p<0.0001 ;$ STP and STFe concentrations, $r_{\mathrm{S}}=0.72$, $p<0.001)$.

Variation in monthly macroinvertebrate taxon richness in ponds

The average number of taxa per pond hydroperiod category and month in the dry year ranged from $4.6 \pm$ 3.1 (SD) for short-hydroperiod ponds in February to $30.8 \pm 8.1$ for long-hydroperiod ponds in April (Fig. 2A). In the wet year, these averages ranged from $5.0 \pm 6.3$ in ephemeral ponds in November to $36.0 \pm$ 10.4 in long-hydroperiod ponds in June. The minimum value $(2 \pm 0)$ was reached in an intermediate hydroperiod pond just before desiccation in July (Fig. 2B). Despite the longer persistence of water in the ponds in the wet year, the monthly pattern of the number of macroinvertebrate taxa was similar between the dry and the wet years (Fig. 2A, B). In ephemeral-, short-, and intermediate-hydroperiod ponds, the number of taxa tended to increase from the time of pond filling until the month prior to desiccation. In contrast, in long-hydroperiod ponds, maximum taxon richness occurred after ephemeral, short, and some intermediate hydroperiod ponds had already become desiccated (Fig. 2A, B).

\section{Environmental variables and}

macroinvertebrate assemblages

CAP analyses revealed that, during the filling phase, macroinvertebrate assemblage composition was mainly influenced by the concentration of TP in the dry year and $\mathrm{pH}$ in the wet year (Table 1). During the dry year's intermediate months of inundation, maximum pond depth and electrical conductivity were the main explanatory variables. During the wet year, $\mathrm{pH}$ and dissolved $\mathrm{O}_{2}$ also became important. During the drying phase of both years, electrical conductivity played a significant role; in contrast, STP concentration and SOM mattered only during the wet year's drying phase. A greater number of significant variables explained the assemblage composition of dispersers than of nondispersers during the filling and drying phases (May in the dry year, November in the wet year, and May and June in the wet year), this pattern was reversed during the intermediate phase of the inundation cycle. Macroinvertebrate predators and nonpredators shared a large number of significant explanatory variables. However, the predator assemblages were explained by a greater number of variables.

\section{Urodele effects}

Urodeles had no effect on the composition of macroinvertebrate assemblages during the dry year (Table 2). In the wet year, they had a significant effect in December, January, February, and May. This pattern was attributable to the presence of T. pygmaeus and P. waltl.

\section{Competitive exclusion and habitat segregation}

In some months, NC scores were not significant, but different partitioning components were significant during different months across the 2 study years (Table 3). This result indicated that negative species checkerboards were present in the overall macroinvertebrate assemblages. $C_{\text {Segr }}$ was significant in February of both years, and $C_{\text {Turn }}$ was significant in April and June of the wet year. For macroinvertebrate 
dispersers and nondispersers, $C_{\text {Segr }}$ was significant in January of the wet year. For nondispersers, it also was significant in April of the wet year. In contrast, $C_{\text {Turn }}$ was significant for macroinvertebrate nondispersers only in January and April of the wet year. For macroinvertebrate predators, partitioning components were significant only in the wet year. $C_{\text {Segr }}$ and $C_{\text {Turn }}$ were both significant in November, January, March, and May. $C_{\text {Turn }}$ alone was significant in April. $C_{\text {Mixed }}$ was significant in January and March. For macroinvertebrate nonpredators, $C_{S e g r}$ was significant for 1 mo each year. $C_{\text {Turn }}$ was significant in June of the wet year, and $C_{\text {Mixed }}$ was significant in March and May of the wet year.

\section{Discussion}

Environmental filters drive species sorting in macroinvertebrate metacommunities and play a key role in the assembly of communities (Patrick and Swan 2011). We confirmed the importance of these environmental filters in community assembly and their independence from variable precipitation. Biotic interactions also play an important role in structuring biological communities. They can lead to the inability of pairs of species to coexist because of competitive exclusion (Stone and Roberts 1990, 1992). However, Heino (2009) found that competitive exclusion and habitat segregation can operate together to structure stream macroinvertebrate assemblages. Our work confirms that both competitive exclusion and habitat segregation influence macroinvertebrate community structure in temporary ponds.

\section{Seasonal environmental variability}

Doñana pond waters generally have moderate nutrient concentrations compared to other Mediterranean temporary ponds (Boix et al. 2008, Della Bella et al. 2008, Waterkeyn et al. 2008). Low nutrient concentrations occurred during the months of maximal pond flooding, whereas peaks of TP occurred as ponds approached desiccation. During maximum flooding, dilution can result in low nutrient and solute concentrations, but concentrations eventually increase again as evaporation drives the ponds to desiccation (Serrano and Toja 1995). Hence, large variations in the depth of the water column are followed by drastic variations in TP. As ponds dried because of evaporation, they became less diluted and underwent a gradual increase in electrical conductivity over the course of the inundation-desiccation cycle. This pattern is common in temporary ponds (Serrano and Toja 1995, Hancock and Timms 2002, Culioli et al. 2006). However, high electrical conductivity values observed in long-hydro- period ponds also can be maintained by the contribution of local and regional groundwater discharge (Sacks et al. 1992).

\section{Seasonal macroinvertebrate variation}

Even though the length of pond hydroperiod differed greatly between our 2 study years, the monthly variation in macroinvertebrate taxon richness was similar. This result suggests that most species successfully completed their life cycles despite the shorter inundation period in the dry than in the wet year and agrees with previous observations (Florencio et al. 2009b). The ability to adjust life-cycle development to pond hydroperiod duration is typical of many species inhabiting temporary ponds and is used to survive pond desiccation (Wiggins et al. 1980, Higgins and Merritt 1999, Williams 2006).

\section{Environmental variables and macroinvertebrate assemblages}

Environmental seasonal variation has widely been suggested as one of the main forces influencing the structure of macroinvertebrate assemblages across inundation-desiccation cycles (Boulton and Lake 1992, Bazzanti et al. 1996, Angélibert et al. 2004, Culioli et al. 2006). In contrast, Florencio et al. (2009b) showed that species' life cycles can influence seasonal variation in macroinvertebrate communities, a finding that highlights the lack of information available on this topic. We showed that environmental filters and biotic interactions both play important roles in determining macroinvertebrate metacommunity structure in temporary ponds.

High values of dissolved $\mathrm{O}_{2}$ concentration and low values of electrical conductivity and $\mathrm{pH}$ occurred during the filling phase of the inundation cycle in both study years. In this phase, the environmental characteristics of ponds, i.e., TP in the dry year and $\mathrm{pH}$ and maximum depth in the wet year, had important effects on the structure of macroinvertebrate assemblages. In general, $\mathrm{N}$ and $\mathrm{P}$ both limit primary production in Mediterranean wetlands (Golterman 1995). We observed differences in TP between ephemeral and short-hydroperiod ponds vs intermediate- and long-hydroperiod ponds just after pond inundation despite its low concentration in November of the wet year (250-350 $\mu \mathrm{g} / \mathrm{L})$.

Pond colonization occurs during the filling phase, which offers a mosaic of niche possibilities for species. Flying dispersers (mainly Coleoptera and Heteroptera species) colonize newly formed ponds, and droughtresistant forms emerge from the sediment (Williams 2006). In our study, similar variables explained the 


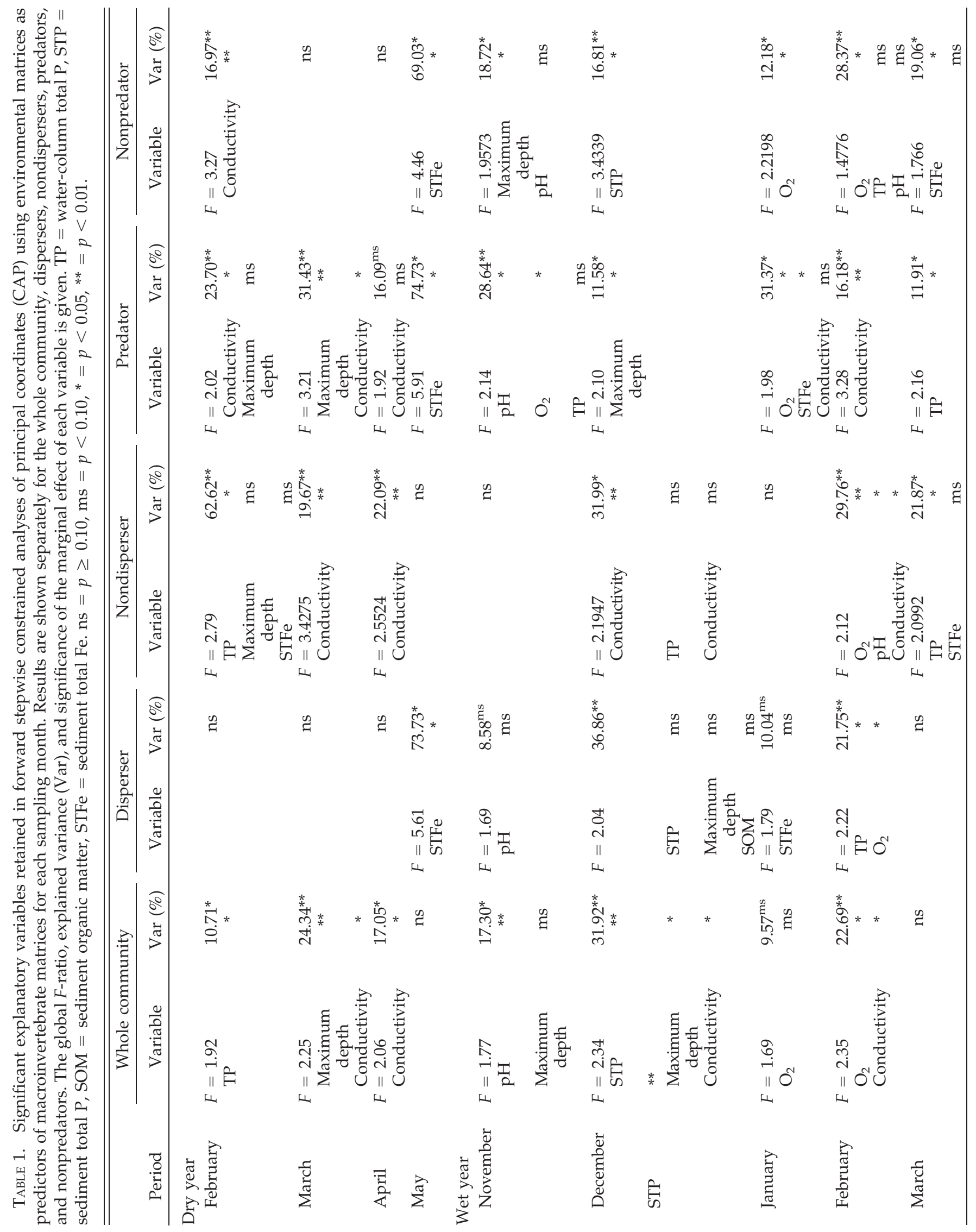




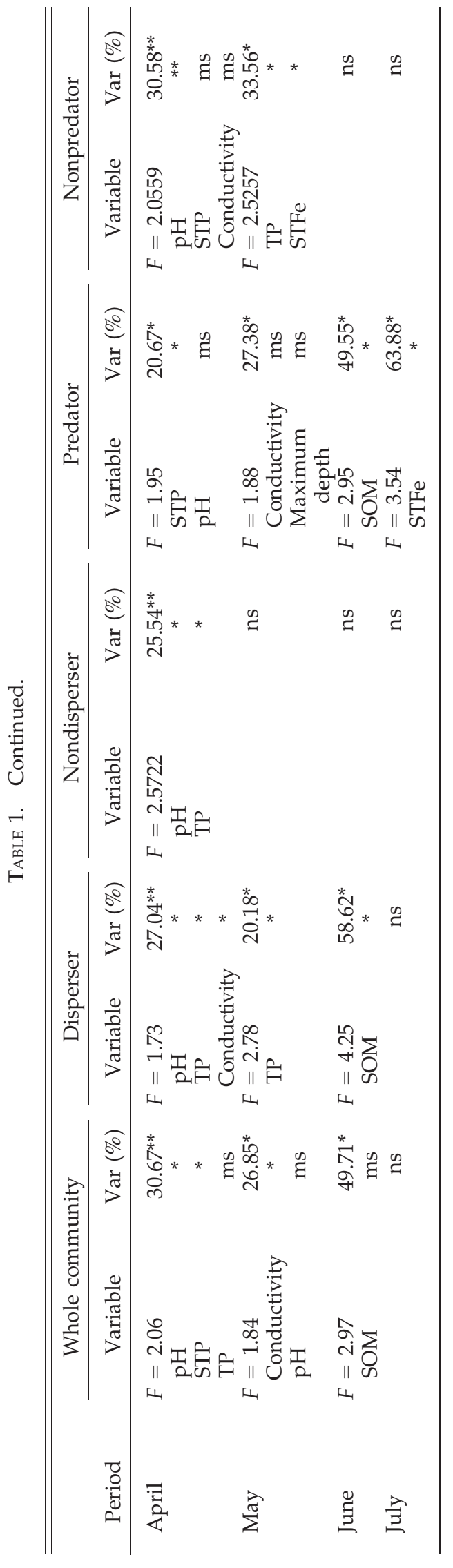

TABLE 2. Significant explanatory variables retained in forward stepwise constrained analyses of principal coordinates (CAP) using urodele larvae as predictors of macroinvertebrate matrices for each sampling month. The global F-ratio, explained variance (Var), and significance of the marginal effect of each variable is given. - indicates urodele larvae were not detected, $\mathrm{Tp}=$ tadpoles of Triturus pygmaeus, $\mathrm{Pw}=$ tadpoles of Pleurodeles waltl. There were no significant effects of Lissotriton boscai. $\mathrm{ns}=p \geq 0.10, \mathrm{~ms}=$ $p<0.10,^{*}=p<0.05,{ }^{* *}=p<0.01$.

\begin{tabular}{lcc}
\hline \hline & \multicolumn{2}{c}{ Whole community } \\
\cline { 2 - 3 } Period & Variables & Var $(\%)$ \\
\hline Dry year & & \\
February & - & - \\
March & & $\mathrm{ns}$ \\
April & & $\mathrm{ns}$ \\
May & & $\mathrm{ns}$ \\
Wet year & & \\
November & $F=1.78$ & $\mathrm{~ns}$ \\
December & $\mathrm{Pw}$ & $9.48^{\mathrm{ms}}$ \\
January & $F=2.42$ & $*$ \\
February & $\mathrm{Pw}$ & $13.12^{*}$ \\
& $\mathrm{~F}=1.81$ & $* .61^{*}$ \\
March & $\mathrm{Tp}$ & $*$ \\
April & & $\mathrm{ns}$ \\
May & $\mathrm{ns}=2.39$ & $\mathrm{~ns}$ \\
& $\mathrm{Tp}$ & $* 31^{* *}$ \\
June & $\mathrm{Pw}$ & $\mathrm{ms}$ \\
July & & $\mathrm{ns}$ \\
\hline
\end{tabular}

presence of predator and nonpredator taxa, results that may indicate that the distribution of macroinvertebrate predators in temporary ponds mirrors that of their prey species (see Englund et al. 2009). For example, during the filling phase, both predators (Notostraca) and nonpredators (Anostraca and Spinicaudata) made up the group of large branchiopods typically found in shallow ephemeral and short-hydroperiod ponds with low conductivity and water-column $\mathrm{P}$ concentration. TP influences large branchiopod community structure in the Camargue wetlands (France), where it is thought to favor the hatching of some species, although a direct causal effect has not been established (Waterkeyn et al. 2009). Predator presence may be reduced in temporary ponds with short hydroperiods (Wellborn et al. 1996), so species occurrence in these ponds could be favored by the almost complete absence of urodeles and other macroinvertebrate predators.

$\mathrm{pH}$ was also an important variable influencing the structure of the macroinvertebrate community during the filling phase of the wet year. The lowest $\mathrm{pH}$ values 
TABLE 3. Significant partitioning of the quantitative index of co-occurrences (NC score) for the entire macroinvertebrate assemblage (whole community) and, separately, for dispersers, nondispersers, predators, and nonpredators. The NC score measures the deviation from random co-occurrence (i.e., higher nonoccurrence of species pairs than expected by chance) and is partitioned into 3 components: 1$)$ segregation that does not stem from species turnover $\left(C_{\text {Segr }}\right.$, i.e., associated with competitive exclusion), 2) segregation that stems from species turnover $\left(C_{T u r n}\right.$, i.e., associated with habitat segregation), and 3$)$ segregation that is caused by both competitive exclusion and habitat segregation $\left(C_{\text {Mixed }}\right)$. Significant $N C$ score partitioning values were higher than those expected by chance after 1000 randomizations. Only those months with significant partitioning are shown (see Methods). $\mathrm{ns}=p \geq 0.10, \mathrm{~ms}=p<0.10,^{*}=p<0.05,{ }^{* *}=p<0.01$.

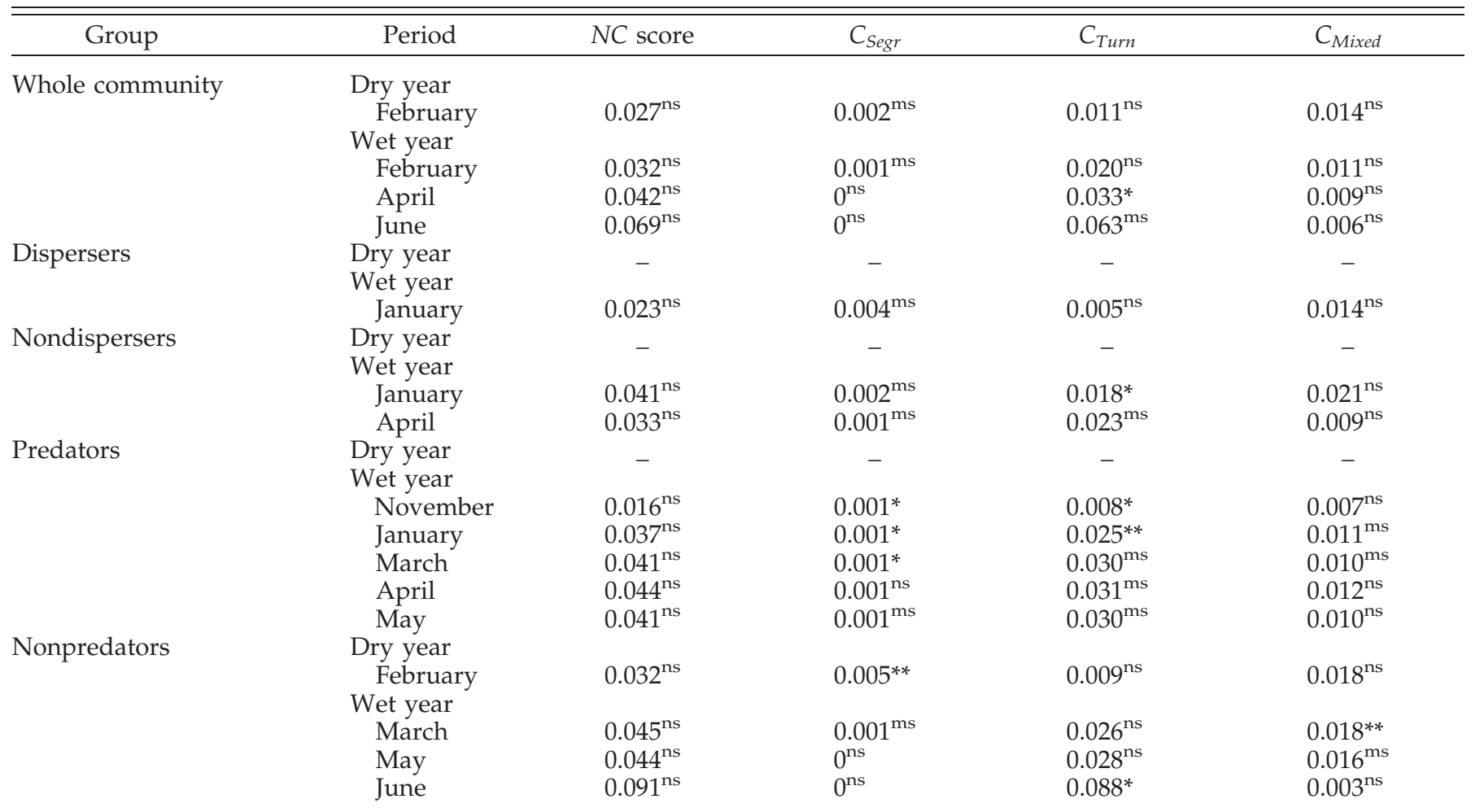

occurred during the initial phase of inundation and, therefore, had a critical influence on initial macroinvertebrate colonization. The heavy rains that filled the ponds could have caused the water to have a slightly low initial pH (Jarrett et al. 1993, Brönmark and Hansson 2005). Humic substances, which are washed from the upland vegetation into Doñana ponds during the filling phase (Serrano 1992, 1994), also could have reduced the initial $\mathrm{pH}$ of the water. During the filling phase, low $\mathrm{pH}$ is an important trigger for resting-egg hatching, mainly for large branchiopods (e.g., Brendonck 1996, Brendonck et al. 1998). However, it also influences the establishment of pioneer dispersers in temporary ponds (Boulton and Lake 1992).

During the intermediate phase of inundation, macroinvertebrates continue their life cycles, and many larval stages become incorporated into the assemblages once reproduction occurs (Williams 2006). These macroinvertebrate larvae are incapable of flight and, therefore, cannot escape unfavorable conditions. Thus, they are particularly vulnerable to pond environmental changes. The great number of larval taxa in the ponds, together with the increasing richness of other nondispersing taxa, may explain the large number of environmental variables that influence macroinvertebrate assemblage composition during this phase. Moreover, the number of macroinvertebrate predators in temporary ponds usually increases with the length of the wet period (Schneider and Frost 1996, Spencer et al. 1999, Bilton et al. 2001a). This correlation also may help explain the great number of variables that affect macroinvertebrate predator presence during the intermediate and the drying phases of the inundation cycle.

During pond desiccation, deoxygenation and high temperatures, accompanied by a drastic reduction in pond surface area and depth and high concentrations of nutrients and solutes (Bazzanti et al. 1996, Higgins and Merritt 1999), are indicative of the general impoverishment of pond environmental conditions. During the drying phase, the assemblage composition 
of macroinvertebrates capable of flight was largely explained by STFe and SOM in the sediment. Both of these variables are related to the hydroperiod of the study ponds (Florencio et al. 2009a), a result suggesting that different macroinvertebrate dispersers prefer different pond hydroperiods. Once intermediatehydroperiod ponds had desiccated, we observed an increase in macroinvertebrate taxon richness in longhydroperiod ponds. This increase could be attributable to dispersal of flying adults to more-permanent ponds (Florencio et al. 2009b). By this time, almost all insects would have completed larval development and emerged as adults, and most crustacean species would have produced drought-resistant eggs (Higgins and Merritt 1999). We suggest that environmental stress and the species saturation of communities, along with the high densities of mainly predaceous macroinvertebrates that occur during pond desiccation, act as triggers in the development of macroinvertebrate strategies to survive the dry season (e.g., Boix et al. 2004, Greig and Wissinger 2010, Jocque et al. 2010).

\section{Urodele effects}

Adult newts enter newly filled ponds and persist therein until approximately February (Díaz-Paniagua et al. 2005). In the dry year, urodeles had no effect on macroinvertebrate assemblages, probably because ponds filled too late in the season and, thus, did not favor reproduction. Most newt females may not reproduce in years in which ponds are not flooded in the autumn (Díaz-Paniagua 1998). In the wet year, we detected a significant effect of urodeles on macroinvertebrate assemblages in December, January, February, and May. During the first months of the inundation cycle, the presence of urodele larvae probably signals the presence of reproductively active adults. The significant effect of urodeles probably is a result of predation by adults on aquatic macroinvertebrates during this important growth period (Díaz-Paniagua et al. 2005). At this point in time, urodele larvae would be too small to prey on macroinvertebrates. In contrast, the effect detected in May seems to be a direct consequence of predation by urodele larvae. By this time, larvae should have reached large size, and macroinvertebrates should be an important part of their diet (Díaz-Paniagua 1980, Díaz-Paniagua et al. 2005).

\section{Competitive exclusion and habitat segregation}

The species checkerboard pattern reveals that competitive exclusion was in operation primarily immediately after pond inundation (February in the dry year), but that both competitive exclusion (February in the wet year) and habitat segregation
(April and June in the wet year) operated together during the intermediate and drying phases of the inundation cycle. This result means that negative species checkerboards in macroinvertebrate assemblages were promoted by both interspecific interactions and resource limitation. Negative species checkerboards in macroinvertebrate dispersers were determined by competitive exclusion in January of the wet year. For macroinvertebrate nondispersers, species occurrences were also determined by habitat segregation in January and April, a result indicating that macroinvertebrates incapable of flight were more vulnerable to the environmental changes in the ponds. Similar negative species checkerboards were detected for macroinvertebrate predators and nonpredators, a result supporting the idea that predator distributions mirror prey distributions. The significant effect of urodeles on macroinvertebrate assemblage structure suggests that urodele predation has an important influence on species checkerboard patterns that are associated with competitive exclusion. This finding is notable considering that few investigators have published assessments of the role of predation in the assembly rules that generate negative species checkerboards in aquatic ecosystems (but see Englund et al. 2009).

\section{Acknowledgements}

We thank Azahara Gómez, Alexandre Portheault, and Carlos Marfil for their assistance with field work. We are grateful to Andrés Millán for helping with the identification of heteropterans and coleopterans and Luz Boyero for revising this manuscript. Jessica Pearce helped edit the English. We thank the Spanish Ministry of Science and Innovation, the European Union Social Fund (FEDER funds) (CGL2006-04458/ BOS and Fellowship grants CSIC-I3P to MF), the Junta de Andalucía (Excellence Research Project 932 and PAI Group RNM128), the Ministerio de Medio Ambiente, Medio Rural y Marino (Research Project 158/2010), and the Direcção Regional da Ciência, Tecnologia e Comunicações (DRCT) for financing MF's current fellowship (M3.1.7/F/002/2011).

\section{Literature Cited}

Angélibert, S., P. Marty, R. Céréghino, And N. Giani. 2004. Seasonal variations in the physical and chemical charasteristics of ponds: implications for biodiversity conservation. Aquatic Conservation: Marine and Freshwater Ecosystems 14:439-456.

BAZZANTI, M., S. BALdOni, AND M. SEminara. 1996. Invertebrate macrofauna of a temporary pond in Central Italy: composition, community parameters and temporal succession. Archiv für Hydrobiologie 137:77-94. 
Bilton, D. T., A. Foggo, and S. D. Rundle. 2001a. Size, permanence and the proportion of predators in ponds. Archiv für Hydrobiologie 151:451-458.

Bilton, D. T., J. R. Freeland, and B. Okamura. 2001b. Dispersal in freshwater invertebrates. Annual Review in Ecology and Systematics 32:159-181.

Blanchet, F. G., P. Legendre, and D. Borcard. 2008. Forward selection of explanatory variables. Ecology 89:2623-2632.

Boix, D., S. Gascón, J. Sala, A. Badosa, S. Brucet, R. LópezFlores, And X. D. Quintana. 2008. Patterns of composition and species richness of crustaceans and aquatic insects along environmental gradients in Mediterranean water bodies. Hydrobiologia 597:53-69.

Boix, D., J. Sala, X. D. Quintana, and R. Moreno-Amichi. 2004. Succession of the animal community in a Mediterranean temporary pond. Journal of the North American Benthological Society 23:29-49.

Boulton, A. J., And P. S. LAKe. 1992. The ecology of two intermittent streams in Victoria, Australia. II. Comparisons of faunal composition between habitats, rivers and years. Freshwater Biology 27:99-121.

BRENDONCK, L. 1996. Diapause, quiescence, hatching requirements: what we can learn from large freshwater branchiopods (Crustacea: Branchiopoda: Anostraca, Notostraca, Conchostraca). Hydrobiologia 320:85-97.

BRENDONCK, L., B. J. Riddoch, V. VAN DE Weghe, AND T. VAN DoOREN. 1998. The maintenance of egg banks in very short-lived pools - a case study with anostracans (Branchiopoda). Archives Hydrobiologica. Special Issues on Advanced Limnology 52:141-161.

BRÖNMARK, C., AND L.-A. HANSSON. 2005. The biology of lakes and ponds. $2^{\text {nd }}$ edition. Oxford University Press, New York.

Culioli, J. L., J. Foata, C. Mori, A. Orsini, and B. Marchand. 2006. Temporal succession of the macroinvertebrate fauna in a Corsican temporary pond. Vie et Milieu-Life and Environment 56:215-221.

Della Bella, V., M. Bazzanti, M. G. Dowgiallo, and M. IBERITE. 2008. Macrophyte diversity and physico-chemical characteristics of Tyrrhenian coast ponds in central Italy: implications for conservation. Hydrobiologia 597: 85-95.

DiAmond, J. M. 1975. Assembly of species communities. Pages 342-444 in M. L. Cody and J. M. Diamond (editors). Ecology and evolution of communities. Harvard University Press, Cambridge, Massachusetts.

Díaz-Paniagua, C. 1980. Interacciones en la alimentación de las larvas de dos especies de tritones (Triturus marmoratus y Triturus boscai). Doñana Acta Vertebrata 7:29-39.

Díaz-Paniagua, C. 1998. Reproductive dynamics of a population of small marbled newts (Triturus marmoratus pygmaeus) in south-western Spain. Herpetological Journal 8:93-98.

Díaz-Paniagua, C., R. Fernández-Zamudio, M. Florencio, P. García-Murillo, C. Gómez-Rodríguez, P. Siljeström, And L. SERRANO. 2010. Temporary ponds from the Doñana National Park: a system of natural habitats for the preservation of aquatic flora and fauna. Limnetica 29:1-18.

Díaz-Paniagua, C., C. Gómez-Rodríguez, A. Portheault, and W. De Bries. 2005. Los Anfibios de Doñana. Organismo
Autónomo de Parques Nacionales. Ministerio de Medio Ambiente, Madrid, Spain.

Englund, G., F. Johansson, P. Olofsson, J. Salonsaari, and J. ÖHman. 2009. Predation leads to assembly rules in fragmented fish communities. Ecology Letters 12: 663-671.

Florencio, M., C. Díaz-Paniagua, L. Serrano, and D. T. BILTON. 2011. Spatio-temporal nested patterns in macroinvertebrate assemblages across a pond network with a wide hydroperiod range. Oecologia (Berlin) 166: 469-483.

Florencio, M., C. Gómez-Rodríguez, A. Gómez, M. Reina, E. Gutiérrez, P. Siljeström, L. Serrano, and C. DíazPANiAguA. 2009a. Towards a quantitative classification of temporary ponds in Doñana (SW Spain). Pages 83-92 in P. Fraga and i. Arguimbau (editors). International Conference on Mediterranean Temporary Ponds (Proceedings and Abstracts). Consell Insular de Menorca, Maó, Spain.

Florencio, M., L. Serrano, C. Gómez-Rodríguez, A. Millán, AND C. DíAz-Paniagua. 2009b. Inter and intra-annual variations of macroinvertebrate assemblages are related to the hydroperiod in Mediterranean temporary ponds. Hydrobiologia 634:167-183.

García-Novo, F., And C. Marín Cabrera. 2006. Doñana. Agua y Biosfera. Doñana 2005. Confederación Hidrográfica del Guadalquivir, Ministerio de Medio Ambiente, Madrid, Spain.

Golterman, H. L. 1995. The labyrinth of nutrient cycles and buffers in wetlands: results based on research in the Camargue (southern France). Hydrobiologia 315:39-58.

Golterman, H. L. 2004. The chemistry of phosphate and nitrogen compounds in sediments. Kluwer Academic Publisher, Dordrecht, The Netherlands.

Gómez-Rodríguez, C., C. Díaz-Paniagua, and J. Bustamante. 2011. Cartografía de lagunas temporales del Parque Nacional de Doñana. Agencia Andaluza del Agua, Junta de Andalucía, Sevilla, Spain. (Available from: http:// www.juntadeandalucia.es/medioambiente/site/web/ rediam)

Gómez-Rodríguez, C., C. Díaz-Paniagua, L. Serrano, M. Florencio, AND A. Portheault. 2009. Mediterranean temporary ponds as amphibian breeding habitats: the importance of preserving pond networks. Aquatic Ecology 43:1179-1191.

GotelLi, N. J., AND D. J. McCABE. 2002. Species co-occurrence: a meta-analysis of J. M. Diamond's assembly rules model. Ecology 83:2091-2096.

Greig, H. S., AND S. A. Wissinger. 2010. Reinforcing abiotic and biotic time constraints facilitate the broad distribution of a generalist with fixed traits. Ecology 91:836-846.

Hancock, M. A., AND B. V. Timms. 2002. Ecology of four turbid clay pans during a filling-drying cycle in the Paroo, semiarid Australia. Hydrobiologia 479:95-107.

HeINO, J. 2009. Species co-occurrence, nestedness and guildenvironment relationships in stream macroinvertebrates. Freshwater Biology 54:1947-1959.

Higgins, M. J., AND R. W. MerRitT. 1999. Invertebrate seasonal patterns and trophic relationships. Pages 279-297 in D. 
Batzer, R. B. Rader, and S. A. Wissinger (editors). Invertebrates in freshwater wetlands of North America. Wiley, New York.

Jarrett, J. N., M. B. Cutler, J. P. Ebersole, and W. G. Hagar. 1993. Seasonal variation in $\mathrm{pH}$ and alkalinity and recruitment of sunfish populations. Freshwater Biology 30:409-417.

JEFFRIES, M. 1994. Invertebrate communities and turnover in wetland ponds affected by drought. Freshwater Biology 32:603-612.

Joceue, M., B. VAnschoenwinkel, AND L. BRendOnCK. 2010. Freshwater rock pools: a review of habitat characteristics, faunal diversity and conservation value. Freshwater Biology 55:1587-1602.

Leibold, M. A., M. Holyoak, N. Mouquet, P. Amarasekare, J. M. Chase, M. F. Hoopes, R. D. Holt, J. B. Shurin, R. LaW, D. Tilman, M. Loreau, and A. Gonzalez. 2004. The metacommunity concept: a framework for multi-scale community ecology. Ecology Letters 7:601-613.

LePS, J., AND P. ŜmILAUER. 2003. Multivariate analysis of ecological data using CANOCO. Cambridge University Press, New York.

Murphy, J., AND J. P. Riley. 1962. A modified single solution method for the determination of soluble phosphate in natural waters. Analytica Chimica Acta 37:31-36.

Oksanen, J., F. G. Blanchet, R. Kindt, P. Legendre, R. B. O'Hara, G. L. Simpson, P. Solymos, M. H. H. Stevens, and H. WAGNER. 2010. vegan: community ecology package. $R$ package. Version 1.18-13/r1328. R Project for Statistical Computing, Vienna, Austria. (Available from: http://RForge.R-project.org/projects/vegan/)

PAtrick, C. J., AND C. M. SwAN. 2011. Reconstructing the assembly of a stream-insect metacommunity. Journal of the North American Benthological Society 30:259-272.

Poff, N. L. 1997. Landscape filters and species traits: towards mechanistic understanding and prediction in stream ecology. Journal of the North American Benthological Society 16:391-409.

Sacks, L. A., J. S. Herman, L. F. Konikow, and A. L. Vela. 1992. Seasonal dynamics of ground-water-lake interactions at Doñana National Park, Spain. Journal of Hydrology 136:123-154.

Schneider, D. W., and T. M. Frost. 1996. Habitat duration and community structure in temporary ponds. Journal of the North American Benthological Society 15:64-86.

SERRANO, L. 1992. Leaching from vegetation of soluble polyphenolic compounds and their abundance in temporary ponds in the Doñana National Park (SW, Spain). Hydrobiologia 123:1-19.

SERRANO, L. 1994. Sources, abundance and disappearance of polyphenolic compounds in temporary ponds of the Doñana National Park (south-western Spain). Australian Journal of Marine and Freshwater Research 45: 1555-1564.

Serrano, L., AND J. Toja. 1995. Limnological description of four temporary ponds in the Doñana National Park (SW, Spain). Archiv für Hydrobiologie 133:497-516.
SERRANO, L., AND J. Toja. 1998. Interannual variability in the zooplankton community of a shallow temporary pond. Verhandlungen der Internationalen Vereinigung für theoretische und angewandte Limnologie 26:1575-1581.

Siljeström, P. A., A. Moreno, L. V. García, And L. E. Clemente. 1994. Doñana National Park (south-west Spain): geomorphological characterization through a soil-vegetation study. Journal of Arid Environments 26:315-323.

Spencer, M., L. Blaustein, S. S. SchwartZ, AND J. E. CohEn. 1999. Species richness and the proportion of predatory animal species in temporary freshwater pools: relationships with habitat size and permanence. Ecology Letters 2:157-166.

StOne, L., AND A. Roberts. 1990. The checkerboard score and species distributions. Oecologia (Berlin) 85:74-79.

Stone, L., AND A. Roberts. 1992. Competitive exclusion, or species aggregation? An aid in deciding. Oecologia (Berlin) 91:419-424.

UlRICH, W. 2012. Turnover-a FORTRAN program for analysis of species associations. Version 1.1. Department of Animal Ecology, Nicholas Copernicus University, Torun, Poland. (Available from: www.umk.pl/ ulrichw)

Ulrich, W., M. Almeida-Neto, and N. J. Gotelli. 2009. A consumer's guide to nestedness analysis. Oikos 118: 3-17.

Ulrich, W., AND N. J. Gotelli. 2012a. A null model algorithm for presence-absence matrices based on proportional resampling. Ecological Modelling 244:20-27.

Ulrich, W., AND N. J. Gotelli. 2012b. Pattern detection in null model analysis. Oikos 22:2-18.

Waterkeyn, A., P. Grillas, E. R. M. De Roeck, L. Boven, And L. BRENDONCK. 2009. Assemblage structure and dynamics of large branchiopods in Mediterranean temporary wetlands: patterns and processes. Freshwater Biology 54:1256-1270.

Waterkeyn, A., P. Grillas, B. Vanschoenwinkel, and L. BRENDONCK. 2008. Invertebrate community patterns in Mediterranean temporary wetlands along hydroperiod and salinity gradients. Freshwater Biology 53: 1808-1822.

Wellborn, G. A., D. K. Skelly, and E. E. Werner. 1996. Mechanisms creating community structure across a freshwater habitat gradient. Annual Review of Ecology and Systematics 27:337-364.

Wiggins, G. B., R. J. MACKAY, AND I. M. SMith. 1980. Evolutionary and ecological strategies of animals in annual temporary pools. Archiv für Hydrobiologie (Supplementband) 58:97-206.

Williams, D. D. 1997. Temporary ponds and their invertebrate communities. Aquatic conservation: Marine and Freshwater Ecosystems 7:105-117.

Williams, D. D. 2006. The biology of temporary waters. Oxford University Press, Oxford, UK. 